\title{
Clethrionomys Tilesius, 1850 is the valid generic name for red-backed voles and Myodes Pallas, 1811 is a junior synonym of Lemmus Link, 1795
}

\author{
Alexey S. Tesakov, Vladimir S. Lebedev, Anna A. Bannikova \\ \& Natalia I. Abramson
}

\begin{abstract}
Red-backed voles are widespread animals in the temperate zone of the Northern Hemisphere, and have considerable economic, medical, and scientific importance; the name Clethrionomys Tilesius, 1850 has been overwhelmingly used for red-backed voles in the extensive literature of the $20^{\text {th }}$ and early $21^{\text {st }}$ centuries. In 2003, Carleton, Musser \& Pavlinov (2003) supported the priority of Myodes Pallas, 1811 over Clethrionomys as the oldest objective synonym of red-backed voles based on the priority of the type designation by Lataste (1883) over that of Hinton (1926). Musser \& Carleton (2005) further advocated this usage in the influential third edition of Mammal Species of the World. An analysis of $19^{\text {th }}$ century zoological literature shows widespread usage of Myodes as the generic name for Norway and Siberian lemmings (currently genus Lemmus Link, 1795). In accordance with that understanding, Coues (1877) gave a diagnosis of Myodes explicitly based on Mus lemmus, which constitutes a valid nomenclatural act designating the type species of the genus Myodes. According to Article 69.1 of the ICZN, all subsequent designations of type species (e.g. that of Lataste, 1883) are not valid. Therefore, Clethrionomys remains the valid genus name for red-backed voles and Myodes is a junior synonym of Lemmus. The incorrect usage of Myodes instead of Clethrionomys for red-backed voles has led to scientific and practical instability and confusion, and should be discontinued.
\end{abstract}

KEY WORDS: nomenclature, taxonomy, red-backed voles, Rodentia, Arvicolidae, Clethrionomys, Myodes.

Alexey S. Tesakov [tesak@ginras.ru], Geological Institute of the Russian Academy of Sciences, Pyzhevsky per. 7, Moscow 119017, Russia; Vladimir S. Lebedev [wslebedev@mail.ru], Zoological Museum of Moscow State University, Bolshaya Nikitskaya ul.6, Moscow 125009, Russia; Anna Bannikova [hylomys@mail.ru], Department of Vertebrate Zoology, Moscow State University, Leninskie Gory, Moscow 119992, Russia; Natalia Abramson [natalia_abr@mail.ru], Zoological Institute of the Russian Academy of Sciences, Universitetskaya nab. 1, Saint Petersburg 199034 Russia.

\section{Clethrionomys Tilesius, 1850 - валидное родовое название для лесных полевок, а Myodes Pallas, 1811 - младший синоним названия Lemmus Link, 1795}

\author{
А.С. Тесаков, В.С. Лебедев, А.А. Банникова, Н.И. Абрамсон
}

РЕЗЮМЕ. Лесные полевки широко распространены в умеренной зоне Северного Полушария. Эти зверьки, имеющие большое экономическое, медицинское и научное значение, преимущественно обозначаются в обширной литературе большей части 20 и начала 21 века как Clethrionomys Tilesius, 1850. В 2003 Карлетон, Массер и Павлинов (2003) высказались в пользу приоритета названия Myodes Pallas, 1811 над Clethrionomys как старшего объективного синонима лесных полевок, основанного на приоритете типа, фиксированного Латастом (1883) над фиксацией Хинтона (1926). Вслед за этим, Массер и Карлетон (2005) обосновали эту таксономию в авторитетном третьем издании "Mammal Species of the World". Анализ зоологической литературы 19-го века показывает широко распространенное использование названия Myodes для норвежских и сибирских леммингов (в настоящее время род Lemmus Link, 1795). В соответствии с этой практикой, Кауз (Coues, 1877) дал диагноз рода Myodes, непосредственно основанный на Mus lemmus. Это является валидным номенклатурным действием, фиксирующим типовой вид рода Myodes. В соответствии со статьей 69.1 МКЗН все позднейшие фиксации (например, фиксация Латаста 1883 г.) — не валидны. Следовательно, Clethrionomys остается валидным названием для лесных полевок, а Myodes является младшим синонимом Lemmus. Некорректное использование названия Myodes вместо Clethrionomys привело к нестабильности и путанице в научном и практическом обиходе. Использование Myodes для лесных полевок должно быть прекращено.

КЛЮЧЕВЫЕ СЛОВА: номенклатура, таксономия, лесные полевки, Rodentia, Arvicolidae, Clethrionomys, Myodes. 


\section{The background and essence of the issue}

Red-backed voles are widespread animals in predominantly wooded habitats of the temperate zone of the Northern Hemisphere. These animals have a considerable economic, medical, and scientific importance. In $19^{\text {th }}$ century zoological literature, species of redbacked voles were assigned to the genera Arvicola, Microtus, Myodes, Lemmus, and Hypudaeus. The genus level taxonomy of this group, and its systematic concept, were gradually stabilized by the second half of the $19^{\text {th }}$ century with a clear diagnosis of the group and the description of the genus Evotomys provided by Coues (1874). The validation of the previously overlooked Clethrionomys Tilesius 1850 by Palmer (1928) brought prolonged taxonomic stability. Since that time, the name Clethrionomys Tilesius, 1850 has been overwhelmingly used for red-backed voles in the extensive literature of the $20^{\text {th }}$ and early $21^{\text {st }}$ centuries. In parallel, there was a long-standing, though quite regional tradition of referring the red-backed voles to the genus Myodes Pallas, 1811 based on the informal usage of Arvicola (Myodes) by de Sélys-Longchamps (1839). In line with this concept, Lataste (1883) designated Myodes rutilus as the type species of the genus Myodes, commonly used in the contemporary literature in Europe and North America for brown lemmings. The action of Lataste appeared to make Myodes the oldest objective synonym among the genus level names validly applied to red-backed voles. Although long known (Kretzoi, 1964), this nomenclatural situation did not influence the predominant scientific usage of Clethrionomys until the publications of Carleton, Musser \& Pavlinov (2003), Musser \& Carleton (2005), and Pavlinov (2006). Their premature usage of Myodes instead of Clethrionomys, widely disseminated in the influential third edition of the Mammal Species of the World (2005), has unfortunately led to taxonomic instability and discontinuity in scientific usage in a very widespread group of organisms. In this article we show the priority of Clethrionomys due to the previously unrecognized valid nomenclatural act of Coues (1877) that designates Mus lemmus Linnaeus as the type species of Myodes Pallas, and thus removes Myodes from the synonymy of red-backed voles.

\section{The nomenclatural history of Myodes and Clethrionomys}

Pallas (1811) described nine species of Myodes, actually all of the mouse-like voles known at that time, diagnosed as small rodents with an obtuse rostrum, ears hidden in fur, and a short tail. Myodes of Pallas included the species lemmus, torquatus, lagurus, oeconomus, arvalis, saxatilis, socialis, gregalis, alliarius, and rutilus.

As a common practice at that time, no type species was explicitly designated, though more typical forms were usually mentioned first. Among characteristic fea- tures of Myodes Pallas noted "ears hidden in fur" and "shortened tail". Indeed, the two first listed species (lemmus, torquatus) have very small hidden ears, and very short tails thus strongly expressing the typical characters of the group. On the contrary, the only redbacked vole among the species originally included in Myodes, rutilus, was placed last in the list by Pallas, which in his time suggested that it least fits the characters. Indeed, rutilus has conspicuous ears and a relatively long tail. In compliance with this understanding, zoologists of the $19^{\text {th }}$ century most frequently applied Myodes to lemmus and torquatus, the brown and collared lemmings.

As an alternative, de Sélys-Longchamps (1839) in his review of European voles used Myodes as one of informal sections of the group. His Myodes comprises exclusively red-backed voles. Characteristic features of the section include rooted molars. De Sélys-Longchamps (1839, p. 87), however, stressed the non-taxonomic essence of his groupings: "Je dois prévenir que je m'opposerais entièrement à l'élévation d'aucune de ces sections au rang de genre ou de sous-genre. [...] Si je me suis permis d'imposer à ces groupes des noms latins pris parmi les synonymes du genre, ce n'est nullement pour qu'ils puissent être introduits dans la nomenclature binaire, mais pour donner aux étrangers l'idée des divers noms que j'ai employés en français." ("I must warn that I would object completely to the elevation of any of these sections to the rank of genus or subgenus. [...] Although I allow myself to impose on these groups Latin names chosen among synonyms of the genus, by no means this is done so that they could be introduced into the binary nomenclature, but to give foreigners an idea of different names I used in French."). This publication encouraged a regional usage of Arvicola (Myodes) as a valid taxonomic placement for redbacked voles, shared in zoological publications of some French-speaking authors, e.g. Fatio (1862) and Lataste (1883a-d, 1886). This usage did not become consistent and universal since red-backed voles (following the usage of Keyserling \& Blasius, 1840) were frequently placed in the separate genus (or subgenus of Arvicola) Hypudaeus Illiger, 1811 (e.g., Fitzinger, 1867, Fatio, 1869).

The usage of Lemmus Link, 1795 as a genus for all lemmings (brown lemmings, collared lemmings, and "steppe lemmings" or lagurines) can also be found in contemporary reviews (Clermont, 1859). But throughout most of the $19^{\text {th }}$ century, the usage of Myodes as a valid name for brown lemmings (usually accompanied by collared lemmings and lagurines) was very common in mammal reviews both in Europe (Keyserling \& Blasius, 1840; Hensel, 1855; Brandt, 1862; Fitzinger, 1867) and North America (Baird, 1857).

Elliott Coues (1874) published a synopsis of North American muroid rodents. To replace the invalid name Hypudaeus Illiger, 1811 (originally including Mus lemmus, arvalis, amphibius) he described a new genus Evotomys for red-backed voles. To the genus Myodes 
Coues allocated the single North American species of brown lemming (M. obensis). Coues also remarked on Myodes that: "Being based upon a long and wellknown animal, the characters need not here be recapitulated." Three years later Coues (1877) published a more detailed account of the North American muroid fauna. In the nomenclatural sense it was a continuation of the 1874 synopsis providing more detail for his system, including such nomenclatural acts as discussing the reasons that Hypudaeus is an invalid name for red-backed voles. He gave a detailed description of the genus Myodes and noted that the "...foregoing diagnosis, so drawn as to exclude Cuniculus [=Dicrostonyx], is based upon Mus lemmus of Linnaeus, and indicates a perfectly natural generic group of Arvicolinae". According to Article 69.1.1 of the International Code of Zoological Nomenclature (ICZN, 1999), which states that "... an author is deemed to have designated one of the originally included nominal species as type species, if he or she states (for whatever reason, right or wrong) that it is the type or type species, or uses an equivalent term, and if it is clear that that author accepts it as the type species", this action of Coues (1877: p.239) constitutes a subsequent designation of Mus lemmus as the type species of the genus Myodes. It is obvious that this action does not fall under the limitations imposed by Article 67.5 of the Code which excludes from valid designation of the type species "...mention of a species as an example of a genus or subgenus, ....mention of a particular character or structure as «type» or «typical» of a genus or subgenus, ... one made in an ambiguous or conditional manner." In case of Coues's treatment of Myodes, we see a deliberate intention to delimit two genera by a straightforward indication of which species the descriptions are based on. There is no doubt that Coues regarded Mus lemmus as the only type species of the genus Myodes.

Slightly later, Fernand Lataste reviewed the history of the classification of voles in detail (Lataste, 1883ad). Lataste noted that among the species included by Pallas (1811) in the genus Myodes, only rutilus did not have previously given subgeneric names. He, therefore, shared the opinion of de Sélys-Longchamps (1839) that Myodes was a subgenus group for red-backed voles. Lataste noted that Evotomys of Coues (1874) equals his usage of Myodes and synonymized Evotomys under Myodes (Lataste, 1883d: 348-349). Lataste referred to the monograph of Coues (1877) as a repetition of Coues (1874) and did not notice in it any nomenclatural acts. Lataste (1883a: 323) diagnosed his "first subgenus of Microtus" by the presence of molar roots, six tubercles in the foot, and eight mammae, and selected "rutilus Pallas" as the type species of the subgenus Myodes (1883d: 349). But this act of Lataste (1883) is later than the designation of Coues, 1877 (Mus lemmus Pallas as the type of Myodes). The designation of Mus rutilus as the type species of Myodes by Lataste (1883) is therefore not valid (ICZN, 1999: Article 69.1). Equally invalid as a designation of the type species of Myodes is the statement of Fatio (1862) that Arvicola (Myodes) "is primarily based on M. glareolus and Nageri" (both currently regarded conspecific under glareolus) as these names were not originally included in Myodes (ICZN, 1999: Article 69.1.1).

The subsequent nomenclatural history of red-backed voles and brown lemmings has been described in recent reviews (e.g. Musser and Carleton, 2005). Myodes was synonymized under Lemmus (Miller, 1896; Palmer, 1904; Hinton, 1926). The latter author (following Barrett-Hamilton, 1913) stated that the genus Myodes is “based upon Mus lemmus Linn.", which was considered a valid type species designation by most taxonomists. Later Palmer (1928) recognized Clethrionomys Tilesius, 1850 as an overlooked senior genus-level synonym for red-backed voles and fixed Mus rutilus as its type species. Clethrionomys has since become the name for red-backed voles that has been almost universally recognized and overwhelmingly used in the scientific literature of the $20^{\text {th }}$ and early $21^{\text {st }}$ century.

\section{Conclusions}

1. Coues (1877) gave the diagnosis of Myodes (brown lemmings) explicitly based on Mus lemmus. According to the ICZN (Article 69.1) his actions constitute a valid designation of Mus lemmus as the type species for the genus Myodes.

2. All subsequent designations, including the designation of Mus rutilus as the type species of Myodes by Lataste (1883), are not valid.

3. Therefore, Clethrionomys Tilesius, 1850 based on Mus rutilus remains the valid genus name for redbacked voles.

4. Myodes Pallas, 1811 is a junior synonym of Lemmus Link, 1795. The use of Myodes for red-backed voles must be discontinued.

5. Although the validity of Clethrionomys follows directly from the regulations of ICZN, to avoid further instability in taxonomic usage in this group of voles, stemming from possible new discoveries in old literature, it is proposed to consider the future inclusion of the name Myodes with the type species Mus lemmus Linnaeus, 1758 in the List of Available Names in Zoology.

ACKNOWLEDGEMENTS. We thank David Mayhew (Leiden), Igor Pavlinov, and Andrey Lissovsky (both Moscow) for valuable comments and discussion, and Boris Kryštufek (Ljubljana) for his useful and helpful review. Critical remarks of an anonymous reviewer helped us to refine our arguments. We are deeply indebted to Chris Bell (Austin), Lutz Maul (Weimar), and Irina Marova (Moscow) for help with the old literature. Svetlana Nikolaeva (London) advised on nomenclatural/ICZN issues.

\section{References}

Carleton M.D., Musser G.G. \& Pavlinov I.Ya. 2003. Myodes Pallas, 1811, is the valid name for the genus of red- 
backed voles // Averianov A.O. \& Abramson N.I. (eds.) Systematics, Phylogeny and Paleontology of Small Mammals. An International Conference Devoted to the 90th Anniversary of Prof. I. M. Gromov. St.Petersburg: Zoological Institute of the Russian Academy of Sciences. P.96-98.

Clermont T.F. 1859. A guide to the quadrupeds and reptiles of Europe. London: John van Voorst. 277 p.

Coues E. 1874. Synopsis of the Muridae of North America // Proceedings of the Academy of Natural Sciences of Philadelphia. Vol.26. Part III. P.173-196.

Coues E. 1877. Monographs of North American Rodentia. I. Muridae. Washington: US Geol. Survey of the territories. Government printing office. 264 p.

Baird S.F. 1857. Mammals: General report upon the zoology of the several Pacific railroad routes. Vol.8, Part $1 / /$ Reports of explorations and surveys to ascertain the most practicable and economical route for a railroad from the Mississippi River to the Pacific Ocean. Washington D.C.: Senate executive document no. $78.757 \mathrm{p}$.

Barrett-Hamilton G.E.H. 1913. A history of British mammals. XIV: Rodentia. London: Gurney and Jackson. P.361-408.

Brandt J.F. 1862. Bemerkungen über die Wirbelthiere des nördlichen europaischen Russlands, besonders des nördlichen Urals // Archiv für wissenschaftliche Kunde von Russland. Berlin: Georg Reimer. T.21. P.493-552.

Fatio V. 1862. Description d'une nouvelle espèce d'Arvicola; le Myodes bicolor // Revue et Magasin de Zoologie. Vol.14. P.257-261.

Fatio V. 1869. Faune des vertébrés de la Suisse. Histoire naturelle des mammifères. Vol.1. Geneve et Bale: H. Georg. $410 \mathrm{p}$.

Fitzinger L.J. 1867. Versuch einer natürlichen Anordung der Nagethiere (Rodentia). 2 // Sitzungsberichte der Bayerischen Akademie der Wissenschaften. Vol.56. No.1. P.57-168.

Hensel R.1855. Beiträge zur Kenntnis fossiler Säugethiere. Insektenfresser und Nagethiere der Diluvialformation // Zeitschrift der Deutschen geologischen Gesellschaft. Vol.7. P.458-501.

Hinton M.A.C. 1926. Monograph of the voles and lemmings (Microtinae) living and extinct. London: British Museum (Natural History). 488 p.

ICZN. 1999. International Code of Zoological Nomenclature. London: International Trust for Zoological Nomenclature. $124 \mathrm{p}$.

Keyserling A. \& Blasius G.H. 1840. Wirbelthiere Europa's. Braunschweig: Friedrich Vieweg \& Sohn. 248 p.

Kretzoi M. 1964. Über einige homonyme und synonyme
Säugetiernamen // Vertebrata Hungarica. Vol.6. No.1-2. P.131-138.

Lataste F. 1883a. Introduction a l'etude des campagnols de France. Historique de la classification des campagnols // Le Naturaliste. Vol.2. No.41. P.323-324.

Lataste F. 1883b. Introduction a l'etude des campagnols de France. Historique de la classification des campagnols // Le Naturaliste. Vol.2. No.42. P.332-334.

Lataste F. 1883c. Introduction a l'etude des campagnols de France. Historique de la classification des campagnols // Le Naturaliste. Vol.2. No.43. P.342-343.

Lataste F. 1883d. Introduction a l'etude des campagnols de France. Historique de la classification des campagnols // Le Naturaliste. Vol.2. No.44. P.347-349.

Lataste F. 1886. Observations sur quelques espèces du genre campagnol (Microtus Schranck, Arvicola Lacépède) // Annali del Museo Civico di Storia Naturale di Genova, Ser.2a, Vol.4. No.24. P.259-274.

Miller G.S. 1896. Genera and subgenera of voles and lemmings // North American Fauna. Vol.12. Washington: U.S. Department of Agriculture. Government printing office. $85 \mathrm{p}$

Musser G.G. \& Carleton M.D. 1993. Family Muridae // Wilson D.E. \& Reeder D.M. (eds.) Mammal Species of the World, a taxonomic and geographic reference. Second Edition. Washington D.C.: Smithsonian Institution Press. P.501-755.

Musser G.G. \& Carleton M.D. 2005. Superfamily Muroidea // Wilson D.E. \& Reeder D.M. (eds.) Mammal Species of the World. Third Edition. Baltimore: The Johns Hopkins University Press. P.894-1531.

Pallas P.S. 1811. Zoographia Rosso-Asiatica. Vol.1. Petrop. $296 \mathrm{p}$.

Palmer T.S. 1904. Index generum mammalium: A list of the genera and families of mammals // North American Fauna. Vol.23. No.1. Washington: U.S. Department of Agriculture. Government printing office. 984 p.

Palmer T.S. 1928. An earlier name for the genus Evotomys / / Proceedings of the Biological Society of Washington. Vol.41. P.87-88.

Pavlinov I.Ya. 2006. [Myodes Pallas 1811, is the valid name for the genus of red-backed voles (Cricetidae)] // Zoologicheskii Zhurnal. Vol.85. No.5. P.667-669 [in Russian].

Sélys-Longchamps E. de. 1839. Études de micromammalogie. Revue des musaraignes, des rats et des campagnols, suivie d'une index methodique des mammiferes d'Europe. Paris: Librairie Encyclopedique de Roret. 165 p.

Tilesius W.G. 1850. Glirium species in Bavaria nonnullae // Isis. Vol.2. P.27-29. 